\title{
A Review on the Thermochemical Pretreatment of Lignocellulosic Biomass for the Production of Coal-grade Solid Biofuel
}

\section{Jyoti Prasad Chakraborty*}

Department of Chemical Engineering and Technology, Indian Institute of Technology (Banaras Hindu University), India

*Corresponding author: Jyoti Prasad Chakraborty, Department of Chemical Engineering and Technology Indian Institute of Technology (Banaras Hindu University), Varanasi-221 005, U.P., India, Tel: +91-979539 6580; Email: jpc.che@itbhu.ac.in

\section{Review Article \\ Volume 4 Issue 2}

Received Date: March 30, 2020

Published Date: April 30, 2020

DOI: $10.23880 /$ ppej-16000219

\section{Abstract}

Thermochemical pretreatment or torrefaction of biomass is rapidly gaining attention because of simple operation, efficacy, and potential to produce valuable solid fuel. Torrefaction of lignocellulosic biomass is reviewed with the purpose of understanding the present state-of-the-art and future prospects. The following aspects have been discussed: biomass selection, optimization of engineering parameters, characterization of solid, liquid, and gaseous products and finally comparison with coal so that torrefied biomass may be blended with coal and utilized in a pulverized coal-fired furnace to produce electricity.

Keywords: Biomass torrefaction; Sub-bituminous coal; Thermochemical pretreatment; Energy yield

\section{Introduction}

Political uncertainty greatly determines the fluctuation in the price of crude oil in the range of USD 30-110 per barrel. Though the reserve of crude oil is limited, adequate supply by Saudi Arabia, Russia, and USA (for shale oil) put pressure on its cost which is now hovering around 25-35 USD per barrel bracket. A high crude price, greenhouse gas (GHG) emission concerns and unpleasant output during processing of coal necessitate research on renewable energy e.g., solar, wind, biomass etc. Solar energy is not available during the night whereas wind energy is available mostly in coastal area. On the other hand, biomass is available in most part of the world and the rate of production of biomass is much faster than the rate of production of coal, crude oil, etc., which usually takes millions of years.

It is well understood that the network of liquid and gaseous transportation fuels is well established throughout the world. Hence, there is a thrust to produce similar fuels from biomass. Pyrolysis and gasification are proven technologies to produce bio-oil and syngas (a mixture of carbon monoxide and hydrogen gas) from biomass. However, a few countries like India, China, Australia, Germany etc. are utilizing coal for the production of electricity as they have a high reserve of coal and available infrastructure for the exploitation of coal. To mitigate environmental pollution and reduce the emission of GHG, there is considerable pressure on these countries to shut or reduce pulverized coal-fired thermal power plants.

India has a very limited reserve of crude oil and natural gas but very good availability of coal. However, Indian coal has low heating value, high ash content and unacceptable sulfur content. The availability of biomass (both agricultural and forest residue) in India is appreciable. The main drawback of biomass is high moisture, high oxygen content, low bulk density and low heating value. If these demerits are improved by means of some suitable process, the modified biomass may be co-combusted with coal in thermal power plants and make the process more environment-friendly, at the same time reduce dependence on imported crude and save money of the Federal government.

Torrefaction is such a process with good potential to convert biomass to value-added solid biofuel. 


\section{Petroleum \& Petrochemical Engineering Journal}

\section{The Objectives of this Review Paper are Mentioned below:}

1. Define torrefaction

2. Summarize experimental and modelling studies on torrefaction and important findings

3. Study the prospects of blending torrefied biomass with coal

\section{Torrefaction}

Torrefaction, also known as mild pyrolysis, is a thermochemical pretreatment step wherein a carbonaceous material is heated in a temperature range of $200-300^{\circ} \mathrm{C}$ in absence of oxygen. A retention time of 30-60 minute is usually adequate; besides, heating rate is varied in the range of $5-20^{\circ} \mathrm{C}$ per minute. A few other variables are particle size, sweeping gas flow rate, biomass type etc. A large sized particle offers mass and heat transfer resistance. Hence, particle size of the order of $1 \mathrm{~mm}$ or less is suitable for torrefaction. Published works suggest that sweeping gas flow rate does not have much influence on the yield or quality of torrefied biomass. Majority of studies employ a fixed-bed reactor for torrefaction; however, a fluidized-bed will ensure better heat transfer characteristics and consequently torrefaction product with uniform quality. Strictly speaking, the range of temperature is decided from the thermogravimetric analysis (TGA) of the specific biomass under inert atmosphere.

The following (Table 1) summarises experimental and modelling studies on torrefaction carried out by different researchers on different biomass species.

\begin{tabular}{|c|c|c|c|c|}
\hline S. No. & Biomass & Operating Conditions & Important Findings & Reference \\
\hline 1 & Sawdust briquette & $\begin{array}{l}\text { T: } 250-270^{\circ} \mathrm{C} \text {; retention time: } 2-4 \mathrm{hr} \text {; } \\
\text { a mild steel chamber was used for } \\
\text { torrefaction with circulation of hot } \\
\text { gas from exchanger }\end{array}$ & $\begin{array}{c}\text { Faster rate and less smoking during } \\
\text { combustion of torrefied wood; } \\
\text { Energy yield: } 76.5-89.6 \% ; \\
\text { H/C and O/C decreased } \\
\end{array}$ & [1] \\
\hline 2 & $\begin{array}{l}\text { Briquette from } \\
\text { wood residue }\end{array}$ & $\begin{array}{c}\mathrm{T}: 220-270^{\circ} \mathrm{C} \text {; retention time: } 0.5-1.5 \\
\mathrm{hr} \text {; inert medium }\end{array}$ & $\begin{array}{c}\text { Temperature has more influence than } \\
\text { retention time; } \\
\text { Energy yield } \sim 50-97 \% \text {; HHV increased } \\
\text { by } 15 \% ; 73 \% \text { decrease in equilibrium } \\
\text { moisture content }\end{array}$ & {$[2]$} \\
\hline 3 & $\begin{array}{l}\text { Briquette from } \\
\text { wood residue }\end{array}$ & $\begin{array}{l}\text { Economic analysis of incorporating } \\
\text { torrefaction within wood briquetting } \\
\text { factory }\end{array}$ & $\begin{array}{c}\text { Improvement in the quality of briquettes; } \\
\text { Break-even point becomes lower; } \\
\text { Multi-product manufacturing facility } \\
\text { possible }\end{array}$ & [3] \\
\hline 4 & Beech and willow & $\begin{array}{l}\text { T: } 200-300^{\circ} \mathrm{C} \text {; retention time: } 10- \\
30 \text { min; gasification of wood and } \\
\text { torrefied wood was considered in } \\
\text { different reactor configurations }\end{array}$ & $\begin{array}{c}\text { Thermodynamic losses during gasification } \\
\text { may be reduced by using torrefaction } \\
\text { pretreatment; } \\
\text { H/C and } \mathrm{O} / \mathrm{C} \text { decreased but HHV increased }\end{array}$ & {$[4]$} \\
\hline 5 & Willow and straw & $\begin{array}{l}\mathrm{T}: 225-300^{\circ} \mathrm{C} \text {; particle size: } 0.7-2.0 \\
\mathrm{~mm} \text { for hardwood, }<5 \mathrm{~mm} \text { for straw }\end{array}$ & $\begin{array}{c}\text { Two-step reaction model proposed; } \\
\text { activation energy } 76 \text { and } 151.7 \mathrm{~kJ} / \mathrm{mol} \text {; } \\
\text { preexponential factor } 2.48^{*} 10^{4} \text { and } \\
1.10^{*} 10^{10} \mathrm{~kg} / \mathrm{kg} \mathrm{s} \\
\text { Majority of hemicellulose degraded }\end{array}$ & {$[5]$} \\
\hline 6 & $\begin{array}{l}\text { Beech, willow, } \\
\text { straw, and larch }\end{array}$ & $\begin{array}{c}\mathrm{T}: 220-300^{\circ} \mathrm{C} \text {; atmospheric pressure; } \\
\text { retention time: } 10-60 \text { min; quartz } \\
\text { fixed-bed reactor }\end{array}$ & $\begin{array}{l}\text { Xylan-containing beech, willow and straw } \\
\text { are more reactive than larch; } \\
\text { Acetic acid and methanol are formed }\end{array}$ & [6] \\
\hline 7 & Eucalyptus & $\begin{array}{c}\text { T: } 240-280^{\circ} \mathrm{C} \text {; inert atmosphere } \\
\left(\mathrm{N}_{2}\right) \text {; retention time: } 0-3 \mathrm{hr} ;<5 \mathrm{~mm} \\
\text { particle size; heating rate: } 10^{\circ} \mathrm{C} / \mathrm{min}\end{array}$ & $\begin{array}{l}\text { Grindability improved; TGA was carried } \\
\text { out; kinetic parameters were estimated; } \\
\text { torrefaction influenced decomposition of } \\
\text { hemicellulose }\end{array}$ & [7] \\
\hline
\end{tabular}




\section{Petroleum \& Petrochemical Engineering Journal}

\begin{tabular}{|c|c|c|c|c|}
\hline 8 & $\begin{array}{l}\text { Reed canary } \\
\text { grass, short } \\
\text { rotation willow } \\
\text { coppice, wheat } \\
\text { straw } \\
\end{array}$ & $\begin{array}{l}\mathrm{T}: 503-563 \mathrm{~K} \text {; inert atmosphere; } \\
\text { retention time: } 10-50 \mathrm{~min} \text {; heating } \\
\text { rate: } 20 \mathrm{~K} / \mathrm{min}\end{array}$ & $\begin{array}{l}\text { Torrefied biomass resembles properties of } \\
\text { low rank coal; } \\
\text { DTA was carried out on combustion of raw } \\
\text { and torrefied biomass }\end{array}$ & [8] \\
\hline 9 & $\begin{array}{c}\text { Reviews } \\
\text { torrefaction of } \\
\text { different biomass }\end{array}$ & $\begin{array}{l}\text { Efficiency of torrefaction, } \\
\text { pelletization and pyrolysis discussed }\end{array}$ & $\begin{array}{c}\text { Techno-economic evaluation of } \\
\text { torrefaction, fast pyrolysis and } \\
\text { pelletization }\end{array}$ & [9] \\
\hline 10 & $\begin{array}{l}\text { Leucaena, woody } \\
\text { biomass }\end{array}$ & $\begin{array}{l}\text { T: } 200-250^{\circ} \mathrm{C} \text {; inert atmosphere; } \\
\text { retention time: } 30 \text { min; }<75 \text { micron } \\
\text { particle size; P: up to } 4 \mathrm{MPa}\end{array}$ & $\begin{array}{c}\text { Solid yield increased with pressure; } \\
\text { HHV increased significantly; } \mathrm{H} / \mathrm{C} \text { and } \mathrm{O} / \mathrm{C} \\
\text { decreased }\end{array}$ & [10] \\
\hline 11 & $\begin{array}{l}\text { Norway spruce } \\
\text { wood chips }\end{array}$ & $\begin{array}{l}\text { T: } 533-583 \mathrm{~K} \text {; inert }\left(\mathrm{N}_{2}\right) \text { and air } \\
\text { atmosphere; retention time: } 8-25 \\
\text { min; heating rate: } 5-20 \mathrm{~K} / \mathrm{min} \text {; } 4-12.5 \\
\mathrm{~kg} / \mathrm{h} \text { mass flow rate of wood chips }\end{array}$ & $\begin{array}{l}\text { Significant decomposition of } \\
\text { hemicellulose; } \\
\text { Appreciable increase in HHV }\end{array}$ & [11] \\
\hline 12 & Scots pine pellets & $\begin{array}{l}\mathrm{T}: 230-270^{\circ} \mathrm{C} \text {; inert atmosphere; } \\
\text { retention time: } 1 \mathrm{hr} ;\end{array}$ & $\begin{array}{l}\text { HHV increased from } 18.37 \text { to } 24.34 \mathrm{MJ} / \mathrm{kg} \text {; } \\
\text { Grinding energy requirements decreased } \\
\text { for torrefied pellets; } \\
\text { More particles were in the smaller size } \\
\text { range }\end{array}$ & [12] \\
\hline 13 & Leucaena & $\begin{array}{l}\text { T: } 240-320^{\circ} \mathrm{C} \text {; inert atmosphere }\left(\mathrm{N}_{2}\right) \text {; } \\
\text { retention time: } 0-1140 \mathrm{~min} \text {; heating } \\
\text { rate: } 10^{\circ} \mathrm{C} / \mathrm{min} \text {; nitrogen flow rate } \\
150 \mathrm{~mL} / \mathrm{min}\end{array}$ & $\begin{array}{c}\text { HHV, ultimate analyses were compared at } \\
\text { similar yields; } \\
\text { Torrefaction at } 320^{\circ} \mathrm{C} \text { altered cellulose } \\
\text { structure }\end{array}$ & [13] \\
\hline 14 & Corncob & $\begin{array}{c}\mathrm{T}: 175-195^{\circ} \mathrm{C} \text {; wet and dry } \\
\text { torrefaction carried out; inert } \\
\text { atmosphere }\left(\mathrm{N}_{2}\right) \text {; high-pressure } \\
\text { batch reactor; corncob:water equals } \\
1: 9 \mathrm{w} / \mathrm{w} \text { in } \mathrm{WT} ; 600 \mathrm{RPM} \text {; heating } \\
\text { rate: } 10^{\circ} \mathrm{C} / \mathrm{min} \text {; }\end{array}$ & $\begin{array}{c}\text { Most of hemicellulose got removed; } \\
\text { Dry torrefaction degraded cellulose as } \\
\text { well; } \\
\text { Wet torrefaction improved yield of } \\
\text { levoglucosan }\end{array}$ & [14] \\
\hline 15 & $\begin{array}{l}\text { Eucalyptus } \\
\text { globulus and } \\
\text { Eucalyptus nitens }\end{array}$ & $\begin{array}{l}\text { TGA carried out: } 20-600^{\circ} \mathrm{C} \text {; heating } \\
\text { rate: } 10^{\circ} \mathrm{C} / \mathrm{min} ; \text { nitrogen atmosphere, } \\
70 \mathrm{~mL} / \mathrm{min}\end{array}$ & $\begin{array}{l}\text { Activation energy of hemicellulose } \\
\text { decomposition was } \sim 121-170 \mathrm{~kJ} / \mathrm{mol} \text {; } \\
295-310^{\circ} \mathrm{C} \text { appeared to be the most } \\
\text { feasible temperature for torrefaction }\end{array}$ & [15] \\
\hline 16 & Rice husk & $\begin{array}{c}\mathrm{T}: 210-270^{\circ} \mathrm{C} \text {; inert atmosphere }\left(\mathrm{N}_{2}\right) \\
200 \mathrm{~mL} / \mathrm{min} \text {; retention time: } 1 \mathrm{hr} ; \\
\text { heating rate: } 10^{\circ} \mathrm{C} / \mathrm{min} ;\end{array}$ & $\begin{array}{c}\text { Torrefaction and organic acid-leaching } \\
\text { pretreatment followed by pyrolysis was } \\
\text { carried out }\end{array}$ & [16] \\
\hline 17 & Rice straw & $\begin{array}{l}\text { T: } 200-300^{\circ} \mathrm{C} \text {; inert atmosphere }\left(\mathrm{N}_{2}\right) ; \\
\text { retention time: } 10-70 \mathrm{~min} ;\end{array}$ & $\begin{array}{c}\text { Torrefaction improved HHV, but decreased } \\
\text { solid and energy yields; } \\
\text { Temperature had more pronounced } \\
\text { influence than retention time }\end{array}$ & [17] \\
\hline 18 & Acacia nilotica & $\begin{array}{l}\mathrm{T}: 220-280^{\circ} \mathrm{C} \text {; inert atmosphere }\left(\mathrm{N}_{2}\right) \\
40 \mathrm{~mL} / \mathrm{min} \text {; retention time: } 20-60 \\
\text { min; heating rate: } 5-15^{\circ} \mathrm{C} / \mathrm{min} \text {; fixed- } \\
\text { bed reactor }\end{array}$ & $\begin{array}{l}\text { Max. } \mathrm{HHV} \text { and energy yield obtained at } \\
252^{\circ} \mathrm{C}, 60 \mathrm{~min} \text { retention time and } 5^{\circ} \mathrm{C} / \mathrm{min} \\
\text { heating rate; } \mathrm{H} / \mathrm{C} \text { and } \mathrm{O} / \mathrm{C} \text { both decreased; } \\
\mathrm{HHV} \text { increased by } 18.62 \% \\
\text { Fuel and flow properties improved } \\
\text { considerably }\end{array}$ & [18] \\
\hline
\end{tabular}




\section{Petroleum \& Petrochemical Engineering Journal}

\begin{tabular}{|c|c|c|c|c|}
\hline 19 & $\begin{array}{l}\text { Pigeon pea stalk } \\
\text { (cajanus cajan) }\end{array}$ & $\begin{array}{l}\mathrm{T}: 200-300^{\circ} \mathrm{C} \text {; inert atmosphere }\left(\mathrm{N}_{2}\right) \text {, } \\
40 \mathrm{~mL} / \mathrm{min} \text {; retention time: } 0-60 \mathrm{~min} \text {; } \\
\text { heating rate: } 5-20^{\circ} \mathrm{C} / \mathrm{min} \text {; cylindrical- } \\
\text { shaped quartz reactor }\end{array}$ & $\begin{array}{c}\text { Temperature had highest impact on } \\
\text { torrefaction; } \\
\text { Optimum condition for maximum } \mathrm{HHV} \\
\text { and energy yield was } 248^{\circ} \mathrm{C}, 60 \mathrm{~min}, 16^{\circ} \mathrm{C} / \\
\text { min; } \\
\text { HHV became } 21.15 \mathrm{MJ} / \mathrm{kg} ; \\
\text { Crystallinity index decreased }\end{array}$ & [19] \\
\hline 20 & Acacia nilotica & $\begin{array}{c}\mathrm{T}: 220-280^{\circ} \mathrm{C} \text {; inert atmosphere }\left(\mathrm{N}_{2}\right) \text {, } \\
40 \mathrm{~mL} / \mathrm{min} \text {; retention time: } 20-60 \\
\text { min; heating rate: } 15^{\circ} \mathrm{C} / \mathrm{min} \text {; fixed- } \\
\text { bed reactor; particle size: } 0.7-1.15 \\
\mathrm{~mm}\end{array}$ & $\begin{array}{c}\mathrm{HHV} \text { increased from } 19.31 \text { to } 24.76 \mathrm{MJ} / \mathrm{kg} \text {; } \\
\text { fixed carbon improved from } 11.35 \text { to } 60.4 \\
\text { wt.\%, whereas the fuel ratio improved } \\
\text { from } 0.13 \text { to } 1.63 \text {; torrefied biomass was } \\
\text { rich in sodium, potassium, calcium etc.; } \\
\text { Moisture absorbed by torrefied biomass } \\
\text { was only } 6.61 \% \text { as compared to } 35.44 \% \text { by } \\
\text { raw biomass }\end{array}$ & [20] \\
\hline 21 & $\begin{array}{l}\text { Pigeon pea stalk } \\
\text { (cajanus cajan) }\end{array}$ & $\begin{array}{l}\text { T: } 220-280^{\circ} \mathrm{C} \text {; inert atmosphere } \\
\left(\mathrm{N}_{2}\right), 40 \mathrm{~mL} / \mathrm{min} \text {; retention time: } \\
20-60 \mathrm{~min} \text {; heating rate: } 15^{\circ} \mathrm{C} / \mathrm{min} \text {; } \\
\text { cylindrical-shaped quartz reactor }\end{array}$ & $\begin{array}{c}\text { Maximum } \mathrm{HHV} \text { and energy yield were } \\
\text { obtained at } 280^{\circ} \mathrm{C} \text { and } 60 \text { min retention } \\
\text { time; } \\
\text { HHV increased by } 37.1 \% \text {; } \\
\text { Flowability improved after torrefaction; } \\
\text { Combustibility index increased by } 76.2 \% \\
\end{array}$ & [21] \\
\hline 22 & $\begin{array}{l}\text { Pigeon pea stalk } \\
\text { (cajanus cajan) }\end{array}$ & $\begin{array}{l}\text { T: } 225-275^{\circ} \mathrm{C} \text {; inert atmosphere } \\
\left(\mathrm{N}_{2}\right), 40 \mathrm{~mL} / \mathrm{min} \text {; retention time: } \\
15-45 \mathrm{~min} \text {; heating rate: } 15^{\circ} \mathrm{C} / \mathrm{min} \text {; } \\
\text { cylindrical-shaped quartz reactor }\end{array}$ & $\begin{array}{c}\text { HHV increased by } 28.6 \% \text { at } 275^{\circ} \mathrm{C} \text { and } 45 \\
\text { min retention time; } \\
\text { Energy density also improved with } \\
\text { severity of torrefaction; } \\
\text { Torrefied biomass exhibited better } \\
\text { combustion properties }\end{array}$ & [22] \\
\hline
\end{tabular}

Table 1: A summary of torrefaction studies in the past few years.

\section{Suitability of Biomass as a Feedstock for Torrefaction}

Biomass consists of hemicellulose, cellulose, lignin, and extractives. Thermogravimetric analysis (TGA) of biomass dictates that within a temperature range of $200-300^{\circ} \mathrm{C}$, majority of hemicellulose gets degraded, thereby making biomass more brittle. Hence, this temperature range is usually considered very much suitable for torrefaction. There is rupture of $\mathrm{C}-\mathrm{O}, \mathrm{O}-\mathrm{O}, \mathrm{O}-\mathrm{H}$ bonds etc., hence formation of $\mathrm{CO}_{2}$, $\mathrm{CO}$, and moisture. A van Krevelen diagram suggests reduction of both $\mathrm{H} / \mathrm{C}$ and $\mathrm{O} / \mathrm{C}$ atomic ratio due to torrefaction, which brings it closer to sub-bituminous coal. Waste biomass, after torrefaction, presents a pathway for waste minimization, waste-to-wealth creation or waste valorization. Hence, biomass appears to be a very much suitable candidate for torrefaction. It may be added that biomass with moisture less than $10 \mathrm{wt} \%$ and moderate ash content is very much suitable for upgrading as solid fuel via torrefaction.

\section{Optimization of Process Variables}

The outcome of any process depends on a set of independent variables. Similarly, torrefaction also depends on independent variables like temperature, heating rate, retention time, particle size, sweeping gas flow rate, biomass type etc. in general, energy yield is a very important parameter which needs to be maximized during torrefaction.

Solid yield $=$ (amount of torrefied biomass/amount of raw biomass) $* 100 \%$

Energy yield $=($ solid yield $) *(\mathrm{HHV}$ of torrefied biomass $/ \mathrm{HHV}$ of raw biomass)

HHV: higher heating value $(\mathrm{MJ} / \mathrm{kg})$

Singh, et al. [18] optimized torrefaction of Acacia nilotica in a fixed-bed reactor using response surface methodology. Maximum higher heating value and energy yield were obtained at $252^{\circ} \mathrm{C}, 60 \mathrm{~min}$ retention time and $5^{\circ} \mathrm{C} / \mathrm{min}$ heating rate. $\mathrm{H} / \mathrm{C}$ and $\mathrm{O} / \mathrm{C}$ atomic ratios in torrefied biomass decreased by 75.54 and $18.62 \%$, respectively, as compared to raw biomass. Singh, et al. [21] carried out optimization of torrefaction for eucalyptus biomass in a tubular quartz reactor. Maximum $\mathrm{HHV}$ was obtained at $280^{\circ} \mathrm{C}$ and $60 \mathrm{~min}$ retention time. Carr Compressibility Index (CCI) and Hausner Ratio (HR) decreased indicating better flow behaviour. The fuel ratio increased significantly, thereby indicating higher 


\section{Petroleum \& Petrochemical Engineering Journal}

fixed carbon and hence better fuel properties. The overall activation energy decreased from 179.1 to $81.7 \mathrm{~kJ} / \mathrm{mol}$, due to torrefaction, indicating lower thermal energy requirement for conversion of torrefied biomass. FT-IR analysis suggested reduction of peak intensity of $\mathrm{O}-\mathrm{H}$ bonds, thus indicating decomposition of hemicellulose.

\section{Characterization of Products}

Torrefied biomass is the main product in torrefaction. It should be characterized for bulk density, HHV, proximate and ultimate analysis, and various fuel and flow properties. Singh, et al. [22] studied torrefaction of pigeon pea stalk, an agricultural residue widely available in India and other Asian countries, in a fixed-bed reactor. They have reported that energy density and HHV increased upon torrefaction. The HHV of torrefied biomass increased by $28.6 \%$ when reaction was carried out at $275^{\circ} \mathrm{C}$ and 45 min retention time. Moisture reabsorption decreased significantly indicating that torrefied biomass may be stored for a long time yet there would be no or minimum degradation. The activation energies of hemicellulose and cellulose decreased to a good extent. Singh, et al. [20] performed torrefaction of Acacia nilotica in a tubular quartz reactor. The HHV and fixed carbon increased from 19.31 to $24.76 \mathrm{MJ} / \mathrm{kg}$ and 11.35 to $60.4 \mathrm{wt} \%$, respectively, when raw biomass was torrefied at $280^{\circ} \mathrm{C}$ for 40 min retention time. ICP-MS analysis revealed that the torrefied biomass was rich in sodium, potassium, calcium, magnesium etc. Moisture absorbed by torrefied biomass was $6.61 \%$ only, as opposed to $35.44 \%$ for raw biomass. Besides, the van Krevelen diagram also clearly suggests that $\mathrm{O} / \mathrm{C}$ and $\mathrm{H} / \mathrm{C}$ ratios of torrefied biomass approach very close to subbituminous coal.

The liquid product from torrefaction does not have much heating value hence cannot be utilized as a transportation fuel. However, several value-added chemicals like acetic acid, furfural, etc. may be extracted from it. The gaseous product consists of $\mathrm{CO}_{2}, \mathrm{CO}$, small amount of $\mathrm{H}_{2}$ and lighter hydrocarbons. This gas stream may be recycled and combusted for thermal energy which, in turn, may be utilized to preheat biomass before it is sent to the torrefaction reactor.

\section{Prospects of Blending Torrefied Biomass with Coal}

Fuel and flow properties of torrefied biomass, as discussed earlier, suggest that it may be blended with subbituminous coal and utilized in a pulverized coal-fired thermal power plant, the blended fuel will have less ash and sulfur but acceptable flow properties as well as heating value. Not many published works are available on the commercial application of torrefied biomass in power generation applications. Research in this direction is therefore required.

\section{Summary and Future Prospects}

Torrefaction appears to be an excellent pretreatment step to convert low-value biomass into value-added solid biofuel. Torrefied biomass has high fixed-carbon and calorific value whereas very low ash and sulfur content. It also exhibits improved flow and fuel properties. These features make it an ideal candidate for blending with coal. Hence, before we can phase out coal, it may be blended with torrefied biomass for producing electricity in thermal plants. It may also be predicted that torrefied biomass alone will be capable of producing electricity via combustion in power plants. It has been observed that there is a need to carry out research on detailed characterization of liquid product obtained from torrefaction and separately catalytic torrefaction.

\section{Nomenclature}

\begin{tabular}{|l|l|}
\hline TGA & Thermogravimetric analysis \\
\hline HHV & Higher heating value (MJ/kg) \\
\hline FTIR & Fourier-Transform Infrared \\
\hline GC-MS & Gas chromatography-mass spectrometry \\
\hline ICP-MS & Inductively coupled plasma-mass spectrometry \\
\hline EY & Energy yield \\
\hline SY & Solid yield \\
\hline H/C & Hydrogen/carbon atomic ratio \\
\hline O/C & oxygen/carbon atomic ratio \\
\hline CCI & Carr compressibility index \\
\hline HR & Hausner ratio \\
\hline
\end{tabular}

\section{References}

1. Pentananunt R, Mizanur Rahman ANM, Bhattacharya SC (1990) Upgrading of biomass by means of Torrefaction. Energy 15(12): 1175-1179.

2. Felfli FF, Luengo CA, Suárez JA, Beatón PA (2005) Wood briquette torrefaction. Energy for Sustainable Development 9(3): 19-22.

3. Felfli FF, Luengo CA, Rocha JD (2005) Torrefied briquettes: technical and economic feasibility and perspectives in the Brazilian market. Energy for Sustainable Development 9(3): 23-29.

4. Prins MJ, Ptasinski KJ, Janssen FJJG (2006) More efficient biomass gasification via Torrefaction. Energy 31(15): 3458-3470.

5. Prins MJ, Ptasinski KJ, Janssen FJJG (2006) Torrefaction of wood: Part 1. Weight loss kinetics. Journal of Analytical and Applied Pyrolysis 77(1): 28-34. 


\section{Petroleum \& Petrochemical Engineering Journal}

6. Prins MJ, Ptasinski KJ, Janssen FJJG (2006) Torrefaction of wood: Part 2. Analysis of products. Journal of Analytical and Applied Pyrolysis 77(1): 35-40.

7. Arias B, Pevida C, Fermoso J, Plaza MG, Rubiera F, et al. (2008) Influence of torrefaction on the grindability and reactivity of woody biomass. Fuel Processing Technology 89(2): 169-175.

8. Bridgeman TG, Jones JM, Shield I, Williams PT (2008) Torrefaction of reed canary grass, wheat straw and willow to enhance solid fuel qualities and combustion properties. Fuel 87(6): 844-856.

9. Uslu A, Faaij APC, Bergman PCA (2008) Pre-treatment technologies, and their effect on international bioenergy supply chain logistics. Techno-economic evaluation of torrefaction, fast pyrolysis and palletisation. Energy 33(8): 1206-1223.

10. Wannapeera J, Worasuwannarak N (2012) Upgrading of woody biomass by torrefaction under pressure. Journal of Analytical and Applied Pyrolysis 96: 173-180.

11. Broström M, Nordin A, Pommer L, Branca C, Di Blasi C (2012) Influence of torrefaction on the devolatilization and oxidation kinetics of wood. Journal of Analytical and Applied Pyrolysis 96: 100-109.

12. Shang L, Nielsen NPK, Dahl J, Stelte W, Ahrenfeldt J, et al. (2012) Quality effects caused by torrefaction of pellets made from Scots pine. Fuel Processing Technology 101: 23-28.

13. Wannapeera J, Worasuwannarak N (2015) Examinations of chemical properties and pyrolysis behaviors of torrefied woody biomass prepared at the same torrefaction mass yields. Journal of Analytical and Applied Pyrolysis 115: 279-287.

14. Zheng A, Zhao Z, Chang S, Huang Z, Zhao K, et al. (2015) Comparison of the effect of wet and dry torrefaction on chemical structure and pyrolysis behavior of corncobs. Bioresource Technology 176: 15-22.
15. Arteaga-Pérez LE, Segura C, Bustamante-García V, Cápiro OG, Jiménez R (2015) Torrefaction of wood and bark from Eucalyptus globulus and Eucalyptus nitens: Focus on volatile evolution vs feasible temperatures. Energy 93(2): 1731-1741.

16. Zhang S, Yinhai S, Dan X, Shuguang Z, Zhang H, et al. (2018) Effects of torrefaction and organic-acid leaching pretreatment on the pyrolysis behavior of rice husk. Energy 149: 804-813.

17. Kai X, Meng Y, Yang T, Lia B, Xing W (2019) Effect of torrefaction on rice straw physicochemical characteristics and particulate matter emission behavior during combustion. Bioresource Technology 278: 1-8.

18. Satyansh S, Jyoti Prasad C, Monoj KM (2019) Optimization of process parameters for torrefaction of Acacia nilotica using response surface methodology and characteristics of torrefied biomass as upgraded fuel. Energy 186: 115865.

19. Rishikesh KS, Jyoti Prasad C, Sarkar A (2020) Optimizing the torrefaction of pigeon pea stalk (cajanus cajan) using response surface methodology (RSM) and characterization of solid, liquid and gaseous products. Renewable Energy 155: 677-690.

20. Satyansh S, Jyoti Prasad C, Monoj KM (2020) Torrefaction of woody biomass (Acacia nilotica): Investigation of fuel and flow properties to study its suitability as a good quality solid fuel. Renewable Energy 153: 711-724.

21. Rishikesh KS, Sarkar A, Jyoti Prasad C (2020) Effect of torrefaction on the physicochemical properties of eucalyptus derived biofuels: estimation of kinetic parameters and optimizing torrefaction using response surface methodology (RSM). Energy 198: 117369.

22. Rishikesh KS, Sarkar A, Jyoti Prasad C (2019) Effect of torrefaction on the physicochemical properties of pigeon pea stalk (Cajanus cajan) and estimation of kinetic parameters. Renewable Energy 138: 805-819. 